\title{
Dexmedetomidine as an Adjuvant in Sciatic Nerve Block for Lower Limb Surgeries: An Observational Study
}

\author{
Krishna Prasad GV 1 , Vipin Sharma Jaishree ${ }^{2}$ \\ ${ }^{1}$ Assistant Professor, Department of Anaesthesiology, MH Krikee, Range Hills, Pune, Maharashtra, India - 411020, ${ }^{2}$ Department of Anaesthesiology, MH \\ Krikee, Range Hills, Pune, Maharashtra, India - 411020.
}

\section{Abstract}

Background: In recent anesthetic practice, peripheral nerve blocks (PNB) are used extensively for surgical anesthesia and non-surgical postop analgesia. PNBs offer many benefits over other anesthetic techniques in a certain population of patients and in some specific clinical setting that may contribute to faster and safer pain relief, increased patient satisfaction, reduced hospital stay, and decreased overall healthcare cost. However, the use of a single PNB is not sufficient enough to block the pain for longer durations. Hence, to prolong the effect of anesthesia without causing any adverse event, adjuvants are injected perineurally along with local anesthetic agents. Aim: The present study was aimed to evaluate the anesthetic efficacy of dexmedetomidine as an adjuvant in sciatic nerve block in lower limb surgery patients. Subjects and Methods: This observational non-randomized study involved 50 patients who were undergoing lower limb surgeries in the study period. The heart rate, blood pressure (both SBP and DBP), and peripheral oxygen saturation were recorded. A VAS score of more than 5 was considered significant and these patients received tramadol injection $(75 \mathrm{mg})$ i.v. As rescue analgesia in the postop period. To prolong the effect of sciatic nerve block, dexmedetomidine $(0.5 \mathrm{mcg} / \mathrm{kg})$ was used. Results: In the maximum number of the patient, the complete block was achieved. Only 6 patients required tramadol injection as the rescue analgesia. No significant post and intraoperative complications were reported after the procedure. Conclusion: It is concluded from the study that the inclusion of dexmedetomidine $(0.5 \mathrm{mcg} / \mathrm{kg})$ in lower limb surgeries was associated with a prolonged duration of analgesia.

Keywords: Peripheral nerve block, femorosciatic nerve block, dexmedetomidine, tramadol.

Corresponding Author: Dr. Krishna Prasad GV, Assistant Professor, Department of Anaesthesiology, MH Krikee, Range Hills, Pune, Maharashtra, India - 411020

Email: drkaypee99@yahoo.com

Received: May 2020

Accepted: May 2020

\section{Introduction}

Peripheral nerve blocks (PNB) are extensively used by anesthesiologists across the globe for both perioperative and non-surgical analgesia. PNBs offer several benefits over neuraxial or general anesthesia (GA) and provide a superior outcome. Some benefits of PNB over GA include superior pain control, reduction in general anesthesia-related adverse events, etc. ${ }^{[1]}$

In general, the local anesthetics work by infiltrating the nerve and blocking the transmission of pain signals to the brain. ${ }^{[2]}$ Such an anesthetic effect lasts for a few hours. Therefore, a major issue with such anesthesia is that the patient may suffer moderate to severe postoperative pain once the effect of anesthesia is over. To address this issue, several drugs have been clinically tested and proven useful as an additive to local anesthetics used for PNB or for local infiltration or intra-articular analgesia. These agents are termed as analgesic adjuvants.

Recently, dexmedetomidine, an $\alpha 2$-adrenoceptor agonist, has proved to be important owing to its high analgesic effect. Few studies have reported the effect of dexmedetomidine in peripheral nerve block studies in humans. These studies have shown that dexmedetomidine is capable of increasing the duration of analgesia exerted by peripheral nerve blocks. Besides, it was also reported that in combination with bupivacaine or ropivacaine, dexmedetomidine is capable of expanding the postoperative analgesic effect. ${ }^{[3-5]}$

However, very few previous studies have been conducted on the effect of dexmedetomidine in a combined femoral sciatic nerve block in patients with lower limb surgeries. To the best of the author's knowledge, none of the studies have evaluated the efficacy of dexmedetomidine $(0.5 \mathrm{mcg} / \mathrm{kg})$ as an adjuvant. This is the primary nerve block used in tibia surgeries. This block will increase postoperative analgesia. Therefore, this study was carried out to evaluate the efficacy of dexmedetomidine as an adjuvant in lower limb orthopedic surgeries along with the sciatic nerve block.

\section{Subjects and Methods}

In this observational study total of 50 patients of ASA Grades I, II, III, and IV were included who were opting for lower limb surgeries. Written consent was obtained from 
them prior to the start of the study. Before the beginning of the study, approval of the Institution's Ethics Committee was also obtained. Patients who are morbidly obese, pregnant and have an allergy of any type were not included in this study. Moreover, unwilling patients were also excluded and patients who had some neurological or neuromuscular disease also were not included in this study.

The combined sciatic and femoral nerve block was used for the surgery to give patients complete anesthesia around the lower limb part. The sciatic nerve block was given using a curvilinear ultrasound probe and nerve stimulator while the patient is in a lateral position using $20 \mathrm{ml}$ of $0.5 \%$ bupivacaine $(\mathrm{P})$, dexmedetomidine was added at a quantity of $0.5 \mathrm{mcg} / \mathrm{kg}$. The femoral nerve block was given using a linear ultrasound probe and nerve stimulator in the supine position, injecting $10 \mathrm{~mL}$ of $0.2 \%$ Lignocaine with adrenaline and $10 \mathrm{~mL}$ of bupivacaine $(\mathrm{P})$. On the day of the operation, the heart rate, peripheral oxygen saturation of the patient, noninvasive blood pressure, including both systolic and diastolic pressures, were recorded and were monitored at every 10 minutes until 90 minutes of the preoperative condition after the nerve block was used.

To prolong the effect of the sciatic nerve block, dexmedetomidine was added additionally. Intravenous (i.v.) lines were secured and all the patients received an injection of paracetamol $1 \mathrm{gm}$ i.v. in every 8 hours throughout the postoperative period for 24 hours. A VAS score of more than 5 was regarded as significant and a tramadol injection (75 $\mathrm{mg}$ ) iv as rescue analgesia was given to those patients. The effect of sciatic nerve block was extended by using dexmedetomidine $(0.50 \mathrm{mcg} / \mathrm{kg})$ as an adjuvant.

The data from this study were collected systematically and were compiled. The compiled data were then analyzed using the SPSS 17.0 software for the relevant conclusion. The data was reported in percentages and numbers. The characteristics of the patient, including the heart rate, SBP and DBP, and pain score was also analyzed in this way.

\section{Results}

The number of male patients was more (86\%) in this study compared with the female patients (14\%). Most of these patients were from ASA grade I and II categories. All the patients underwent surgeries below the knee level with no failure rate was reported. The duration of surgery was comparable in all the patients. There was no complication was reported after surgery and only in 6 patients rescue analgesia was given. Not much change was observed in the preoperative and postoperative SBP and DBP measurements [Table 3 \& Table 4].

Similarly, heart rate was also found to be constant in both pre and postoperative instances. The addition of dexmedetomidine was able to increase the duration of postoperative analgesia in most of the patients. The pain score was found to be absent in $18 \%$ of the patients in the first 1 hour. However, as time progresses, the pain score started increasing. After 12 hours, one patient complained of severe pain and tramadol injection was given as the rescue analgesic.

The complete block was achieved in $92 \%$ of the patients. None of the patients had any previous cardiovascular or neurological complications. No significant change in the preoperative and postoperative pulse and blood pressure was reported in this study.

\section{Discussion}

The efficacy of $50 \mu \mathrm{g}$ of dexmedetomidine was studied in the present study when used in combination with sciatic and femoral nerve block in patients undergoing lower limb surgeries. It was reported in the study that dexmedetomidine increases the duration of postoperative analgesia in the above-mentioned surgery patients.

Dexmedetomidine is an active isomer of medetomidine. This is an effective $\alpha 2$-adrenoceptor agonist with an $\alpha 2: \alpha 1$ selectivity binding ratio of 1620:1. This particular adjuvant decreased the pain by activating the $\alpha 2$-adrenoceptors present in the CNS and thus inhibiting the effect of norepinephrine. ${ }^{[6]}$ Previous studies have reported that dexmedetomidine increases the effect of local analgesics by increasing the effect of motor and sensory blockade. ${ }^{[7]}$ Moreover, it also works in a dose-dependent manner and previous studies have shown that in humans, it has efficacious effects. To date, no studies on human subjects had shown the presence of neurotoxicity when dexmedetomidine was used. However, no neurotoxicity of dexmedetomidine was reported in spinal anesthesia models of animals. ${ }^{[8]}$

Previous studies showed that dexmedetomidine can prolong the blockade of the peripheral nerve by 200 minutes. In a systematic review, it was reported that dexmedetomidine can effectively extend the duration of long-acting local anesthetics used in spinal blocks. They have also mentioned that in the peripheral application category, dexmedetomidine even some times exceeds the effect of clonidine. Different doses ranging from $1 \mu \mathrm{g} / \mathrm{kg}, 30 \mu \mathrm{g}, 100 \mu \mathrm{g}$ and $0.75 \mu \mathrm{g} / \mathrm{kg}$ of additive was used in different studies. This meta-analysis showed the presence of reversible bradycardia in less than $10 \%$ time. $^{[9]}$

Marhofet et al. (2013) have reported that perineural administration of dexmedetomidine with $0.75 \%$ concentration of ropivacaine increases the ulnar nerve block by $60 \% .^{[4]}$ Ammar and Mehmoud (2012) reported the effectiveness of dexmedetomidine as an adjuvant. Moreover, they have also reported that in patients requiring infraclavicular brachial plexus blockade, it effectively extends the analgesic effect, decreases pain score and reduces use of supplemental opioid requirements. ${ }^{[5]}$

In accordance with the previous studies, as stated in the above section, the result of this study also showed that the addition of dexmedetomidine extends the postoperative analgesic effect in lower limb surgery patients. The report of this study also showed that in only 6 patients, rescue analgesics were administered after 12 hours post-surgery.

In the past, several studies had shown the efficacy of the sciatic and femoral nerve block combination in lower limb surgery patients. Aksoy et al. have compared the efficacy of sciatic nerve block with spinal anesthesia given in a continuous mode in high-risk aged patients who were scheduled for elective hip replacement surgery. They have reported that the sciatic nerve block produces lesser 
hemodynamic changes compared with the spinal anesthesia cases. ${ }^{[10]}$

In another study Akkaya et al. have conducted a comparative study between the ultrasound-guided sciatic and femoral nerve block and spinal anesthesia in total knee arthroplasty patients. They have reported that peripheral nerve block can be used in these patients effectively and safely. Moreover, they have also reported that in patients whom spinal anesthesia is difficult to administer, an alternative method of analgesia using sciatic and femoral nerve block can be proved to be useful. ${ }^{[11]}$

In another study, Bansal et al. have compared the efficacy of femoral and sciatic nerve block with ropivacaine alone and by adding fentanyl. ${ }^{[12]}$ Similar to this study, we have used dexmedetomidine along with sciatic nerve block for better analgesic effect. It has been shown that a dose of $3 \mu \mathrm{g}$ of this additive prolongs the motor and sensory blockade effect of intrathecal bupivacaine. ${ }^{[13]}$

Previous studies have reported that dexmedetomidine may cause several side effects, including hypotension, hypertension, hyperglycemia and bradycardia. In a study by Helal et al. (2016) it was reported that $100 \mu \mathrm{g}$ dexmedetomidine to bupivacaine $(0.5 \%)$ increases analgesia in patients undergoing combined sciatic and femoral nerve block. however, this prolonged analgesic effect was associated with significant bradycardia. ${ }^{[14]}$ In contrast to this finding, this present study no such decreased heart rate was reported in patients treated with dexmedetomidine.

In this study, not a single patient had any postoperative or intraoperative complications. This result is similar to the findings of Palkhiwala and Bhatt. ${ }^{[15]}$ They have reported that peripheral nerve block can replace the general anesthesia in patients who are undergoing .elective or emergency lower limp surgeries. In a similar study by Zaric et al, it was reported that compared with the epidural group in the PNB group, the presence of side effects was very low (p. 0.05). ${ }^{[16]}$ Raj Kumar et al also reported that peripheral nerve block has no intraoperative and postoperative side effects. ${ }^{[17]}$

Apart from various clinical significances, this also has some limitations. The recruitment of a control group would have proved this study to be more effective. Secondly, as there was no effective dose of the dexmedetomidine was identified clinically, we have used a dose that is in accordance with other studies that have used adjuvants. Third, this study was not designed to test the onset of motor and sensory blockade arising after the addition of dexmedetomidine.

Table 1: Demographic parameters of the study

\begin{tabular}{|l|l|l|}
\hline Gender & Number & Percentage \\
\hline & 43 & 86.0 \\
\hline Male & 7 & 14.0 \\
\hline Female & & \\
\hline ASA Grade & 23 & 46.0 \\
\hline I & 22 & 44.0 \\
\hline II & 3 & 6.0 \\
\hline III & 2 & 4.0 \\
\hline IV & & \\
\hline Duration of surgery & 6 & 12.0 \\
\hline 1 & 36 & 72.0 \\
\hline 2 & 8 & 16.0 \\
\hline 3 & \multicolumn{2}{|l}{}
\end{tabular}

Table 2: Heart rate before the operation

\begin{tabular}{|c|c|c|c|c|c|c|c|c|c|c|c|c|c|c|c|c|c|c|c|c|}
\hline & \multicolumn{2}{|c|}{$\begin{array}{l}\text { Preop } \\
\text { HR }\end{array}$} & \multicolumn{2}{|c|}{$\begin{array}{l}\text { HR (10 } \\
\text { min) }\end{array}$} & \multicolumn{2}{|c|}{$\begin{array}{l}\text { HR (20 } \\
\text { min) }\end{array}$} & \multicolumn{2}{|c|}{$\begin{array}{l}\text { HR (30 } \\
\text { min) }\end{array}$} & \multicolumn{2}{|c|}{$\begin{array}{l}\text { HR (40 } \\
\text { min) }\end{array}$} & \multicolumn{2}{|c|}{$\begin{array}{l}\text { HR (50 } \\
\text { min) }\end{array}$} & \multicolumn{2}{|c|}{$\begin{array}{l}\text { HR (60 } \\
\text { min) }\end{array}$} & \multicolumn{2}{|c|}{$\begin{array}{l}\text { HR (70 } \\
\text { min) }\end{array}$} & \multicolumn{2}{|c|}{$\begin{array}{l}\text { HR (80 } \\
\text { min) }\end{array}$} & \multicolumn{2}{|c|}{$\begin{array}{l}\text { HR (90 } \\
\text { min) }\end{array}$} \\
\hline & \begin{tabular}{|l|} 
Nu \\
mb \\
er
\end{tabular} & $\begin{array}{l}\text { Perc } \\
\text { enta } \\
\text { ge }\end{array}$ & $\begin{array}{l}\text { Nu } \\
\text { mb } \\
\text { er }\end{array}$ & $\begin{array}{l}\text { Perc } \\
\text { enta } \\
\text { ge }\end{array}$ & $\begin{array}{l}\mathrm{Nu} \\
\mathrm{mb} \\
\mathrm{er}\end{array}$ & $\begin{array}{l}\text { Perc } \\
\text { enta } \\
\text { ge }\end{array}$ & $\begin{array}{l}\text { Nu } \\
\text { mb } \\
\text { er }\end{array}$ & $\begin{array}{l}\text { Perc } \\
\text { enta } \\
\text { ge }\end{array}$ & $\begin{array}{l}\text { Nu } \\
\text { mb } \\
\text { er }\end{array}$ & $\begin{array}{l}\text { Perc } \\
\text { enta } \\
\text { ge }\end{array}$ & $\begin{array}{l}\text { Nu } \\
\text { mb } \\
\text { er }\end{array}$ & $\begin{array}{l}\text { Perc } \\
\text { enta } \\
\text { ge }\end{array}$ & $\begin{array}{l}\text { Nu } \\
\text { mb } \\
\text { er }\end{array}$ & $\begin{array}{l}\text { Perc } \\
\text { enta } \\
\text { ge }\end{array}$ & $\begin{array}{l}\text { Nu } \\
\text { mb } \\
\text { er }\end{array}$ & $\begin{array}{l}\text { Perc } \\
\text { enta } \\
\text { ge }\end{array}$ & $\begin{array}{l}\text { Nu } \\
\text { mb } \\
\text { er }\end{array}$ & $\begin{array}{l}\text { Perc } \\
\text { enta } \\
\text { ge }\end{array}$ & $\begin{array}{l}\text { Nu } \\
\text { mb } \\
\text { er }\end{array}$ & $\begin{array}{l}\text { Perc } \\
\text { enta } \\
\text { ge }\end{array}$ \\
\hline $\begin{array}{l}< \\
7 \\
0\end{array}$ & 8 & 16.0 & 21 & 42.0 & 24 & 48.0 & 34 & 68.0 & 45 & 90.0 & 40 & 80.0 & 46 & 92.0 & 46 & 92.0 & 41 & 82.0 & 34 & 68.0 \\
\hline $\begin{array}{l}7 \\
0 \\
- \\
8 \\
0\end{array}$ & 31 & 62.0 & 21 & 42.0 & 22 & 44.0 & 16 & 32.0 & 4 & 8.0 & 6 & 12.0 & 3 & 6.0 & 4 & 8.0 & 8 & 16.0 & 13 & 26.0 \\
\hline $\begin{array}{l}> \\
8 \\
0\end{array}$ & 11 & 22.0 & 8 & 16.0 & 4 & 8.0 & 50 & $\begin{array}{l}100 . \\
0\end{array}$ & 1 & 2.0 & 4 & 8.0 & 1 & 2.0 & & & 1 & 2.0 & 3 & 6.0 \\
\hline
\end{tabular}

Table 3: Systolic blood pressure

\begin{tabular}{|c|c|c|c|c|c|c|c|c|c|c|c|c|c|c|c|c|c|c|c|c|}
\hline & \multicolumn{2}{|c|}{$\begin{array}{l}\text { Pre op } \\
\text { SBP }\end{array}$} & \multicolumn{2}{|c|}{$\begin{array}{l}\text { SBP (10 } \\
\text { min) }\end{array}$} & \multicolumn{2}{|c|}{$\begin{array}{l}\text { SBP (20 } \\
\text { min) }\end{array}$} & \multicolumn{2}{|c|}{$\begin{array}{l}\text { SBP (30 } \\
\text { min) }\end{array}$} & \multicolumn{2}{|c|}{$\begin{array}{l}\text { SBP (40 } \\
\text { min) }\end{array}$} & \multicolumn{2}{|c|}{$\begin{array}{l}\text { SBP (50 } \\
\text { min) }\end{array}$} & \multicolumn{2}{|c|}{$\begin{array}{l}\text { SBP (60 } \\
\text { min) }\end{array}$} & \multicolumn{2}{|c|}{$\begin{array}{l}\text { SBP (70 } \\
\text { min) }\end{array}$} & \multicolumn{2}{|c|}{$\begin{array}{l}\text { SBP (80 } \\
\text { min) }\end{array}$} & \multicolumn{2}{|c|}{$\begin{array}{l}\text { SBP (90 } \\
\text { min) }\end{array}$} \\
\hline & $\begin{array}{l}\mathrm{Nu} \\
\mathrm{mb} \\
\mathrm{er}\end{array}$ & $\begin{array}{l}\text { Perc } \\
\text { enta } \\
\text { ge }\end{array}$ & $\begin{array}{l}\mathbf{N u} \\
\text { mb } \\
\text { er }\end{array}$ & $\begin{array}{l}\text { Perc } \\
\text { enta } \\
\text { ge }\end{array}$ & $\begin{array}{l}\mathbf{N u} \\
\text { mb } \\
\text { er }\end{array}$ & $\begin{array}{l}\text { Perc } \\
\text { enta } \\
\text { ge }\end{array}$ & $\begin{array}{l}\text { Nu } \\
\text { mb } \\
\text { er }\end{array}$ & $\begin{array}{l}\text { Perc } \\
\text { enta } \\
\text { ge }\end{array}$ & $\begin{array}{l}\mathbf{N u} \\
\text { mb } \\
\text { er }\end{array}$ & $\begin{array}{l}\text { Perc } \\
\text { enta } \\
\text { ge }\end{array}$ & $\begin{array}{l}\mathrm{Nu} \\
\mathrm{mb} \\
\text { er }\end{array}$ & $\begin{array}{l}\text { Perc } \\
\text { enta } \\
\text { ge }\end{array}$ & $\begin{array}{l}\mathrm{Nu} \\
\mathrm{mb} \\
\text { er }\end{array}$ & $\begin{array}{l}\text { Perc } \\
\text { enta } \\
\text { ge }\end{array}$ & $\begin{array}{l}\mathbf{N u} \\
\text { mb } \\
\text { er }\end{array}$ & $\begin{array}{l}\text { Perc } \\
\text { enta } \\
\text { ge }\end{array}$ & $\begin{array}{l}\mathrm{Nu} \\
\mathrm{mb} \\
\text { er }\end{array}$ & $\begin{array}{l}\text { Perc } \\
\text { enta } \\
\text { ge }\end{array}$ & $\begin{array}{l}\mathrm{Nu} \\
\mathrm{mb} \\
\mathrm{er}\end{array}$ & $\begin{array}{l}\text { Perc } \\
\text { enta } \\
\text { ge }\end{array}$ \\
\hline $\begin{array}{l}< \\
1 \\
2 \\
0\end{array}$ & 22 & 44.0 & 50 & $\begin{array}{l}100 . \\
0\end{array}$ & 39 & 78.0 & 43 & 86.0 & 47 & 94.0 & 49 & 98.0 & 49 & 98.0 & 50 & $\begin{array}{l}100 . \\
0\end{array}$ & 48 & 96.0 & 42 & 84.0 \\
\hline $\begin{array}{l}1 \\
2 \\
0- \\
1 \\
4 \\
0\end{array}$ & 24 & 48.0 & & & 10 & 20.0 & 7 & 14.0 & 2 & 4.0 & 1 & 2.0 & 1 & 2.0 & & & 2 & 4.0 & 8 & 16.0 \\
\hline
\end{tabular}




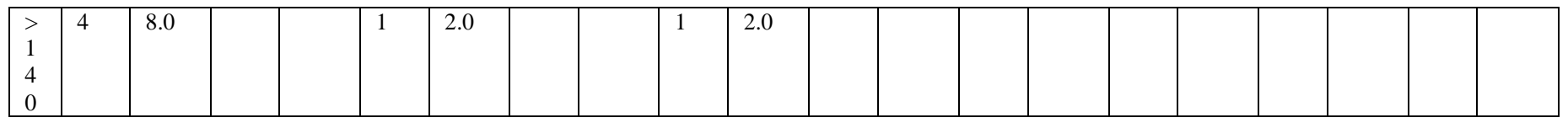

\begin{tabular}{|c|c|c|c|c|c|c|c|c|c|c|c|c|c|c|c|c|c|c|c|c|}
\hline & & & & & & & & & \multicolumn{12}{|c|}{ Table 4: Diastolic blood pressure } \\
\hline & \multicolumn{2}{|c|}{$\begin{array}{l}\text { Pre op } \\
\text { DBP }\end{array}$} & \multicolumn{2}{|c|}{$\begin{array}{l}\text { DBP (10 } \\
\min )\end{array}$} & \multicolumn{2}{|c|}{$\begin{array}{l}\text { DBP (20 } \\
\text { min) }\end{array}$} & \multicolumn{2}{|c|}{$\begin{array}{l}\text { DBP (30 } \\
\text { min) }\end{array}$} & \multicolumn{2}{|c|}{$\begin{array}{l}\text { DBP (40 } \\
\text { min) }\end{array}$} & \multicolumn{2}{|c|}{$\begin{array}{l}\text { DBP (50 } \\
\text { min) }\end{array}$} & \multicolumn{2}{|c|}{$\begin{array}{l}\text { DBP (60 } \\
\text { min) }\end{array}$} & \multicolumn{2}{|c|}{$\begin{array}{l}\text { DBP (70 } \\
\text { min) }\end{array}$} & \multicolumn{2}{|c|}{$\begin{array}{l}\text { DBP (80 } \\
\text { min) }\end{array}$} & \multicolumn{2}{|c|}{$\begin{array}{l}\text { DBP (90 } \\
\text { min) }\end{array}$} \\
\hline & \begin{tabular}{|l|}
$\mathrm{Nu}$ \\
$\mathrm{mb}$ \\
$\mathrm{er}$
\end{tabular} & $\begin{array}{l}\text { Perc } \\
\text { enta } \\
\text { ge }\end{array}$ & $\begin{array}{l}\mathrm{Nu} \\
\mathrm{mb} \\
\mathrm{er}\end{array}$ & $\begin{array}{l}\text { Perc } \\
\text { enta } \\
\text { ge }\end{array}$ & $\begin{array}{l}\text { Nu } \\
\text { mb } \\
\text { er }\end{array}$ & $\begin{array}{l}\text { Perc } \\
\text { enta } \\
\text { ge }\end{array}$ & $\begin{array}{l}\text { Nu } \\
\text { mb } \\
\text { er }\end{array}$ & $\begin{array}{l}\text { Perc } \\
\text { enta } \\
\text { ge }\end{array}$ & $\begin{array}{l}\mathrm{Nu} \\
\mathrm{mb} \\
\mathrm{er}\end{array}$ & $\begin{array}{l}\text { Perc } \\
\text { enta } \\
\text { ge }\end{array}$ & $\begin{array}{l}\mathrm{Nu} \\
\mathrm{mb} \\
\mathrm{er}\end{array}$ & $\begin{array}{l}\text { Perc } \\
\text { enta } \\
\text { ge }\end{array}$ & $\begin{array}{l}\text { Nu } \\
\text { mb } \\
\text { er }\end{array}$ & $\begin{array}{l}\text { Perc } \\
\text { enta } \\
\text { ge }\end{array}$ & $\begin{array}{l}\text { Nu } \\
\text { mb } \\
\text { er }\end{array}$ & $\begin{array}{l}\text { Perc } \\
\text { enta } \\
\text { ge }\end{array}$ & $\begin{array}{l}\text { Nu } \\
\text { mb } \\
\text { er }\end{array}$ & $\begin{array}{l}\text { Perc } \\
\text { enta } \\
\text { ge }\end{array}$ & $\begin{array}{l}\text { Nu } \\
\text { mb } \\
\text { er }\end{array}$ & $\begin{array}{l}\text { Perc } \\
\text { enta } \\
\text { ge }\end{array}$ \\
\hline $\begin{array}{l}< \\
8 \\
0\end{array}$ & 31 & 62.0 & 50 & $\begin{array}{l}100 . \\
0\end{array}$ & 32 & 64.0 & 39 & 78.0 & 42 & 84.0 & 49 & 98.0 & 50 & $\begin{array}{l}100 . \\
0\end{array}$ & 50 & $\begin{array}{l}100 . \\
0\end{array}$ & 50 & $\begin{array}{l}100 . \\
0\end{array}$ & 50 & $\begin{array}{l}100 . \\
0\end{array}$ \\
\hline $\begin{array}{l}8 \\
0 \\
- \\
9 \\
0\end{array}$ & 16 & 32.0 & & & 14 & 28.0 & 7 & 14.0 & 6 & 12.0 & 0 & 0 & & & & & & & & \\
\hline $\begin{array}{l}> \\
9 \\
0\end{array}$ & 3 & 6.0 & & & 4 & 8.0 & 4 & 8.0 & 2 & 4.0 & 1 & 2.0 & & & & & & & & \\
\hline
\end{tabular}

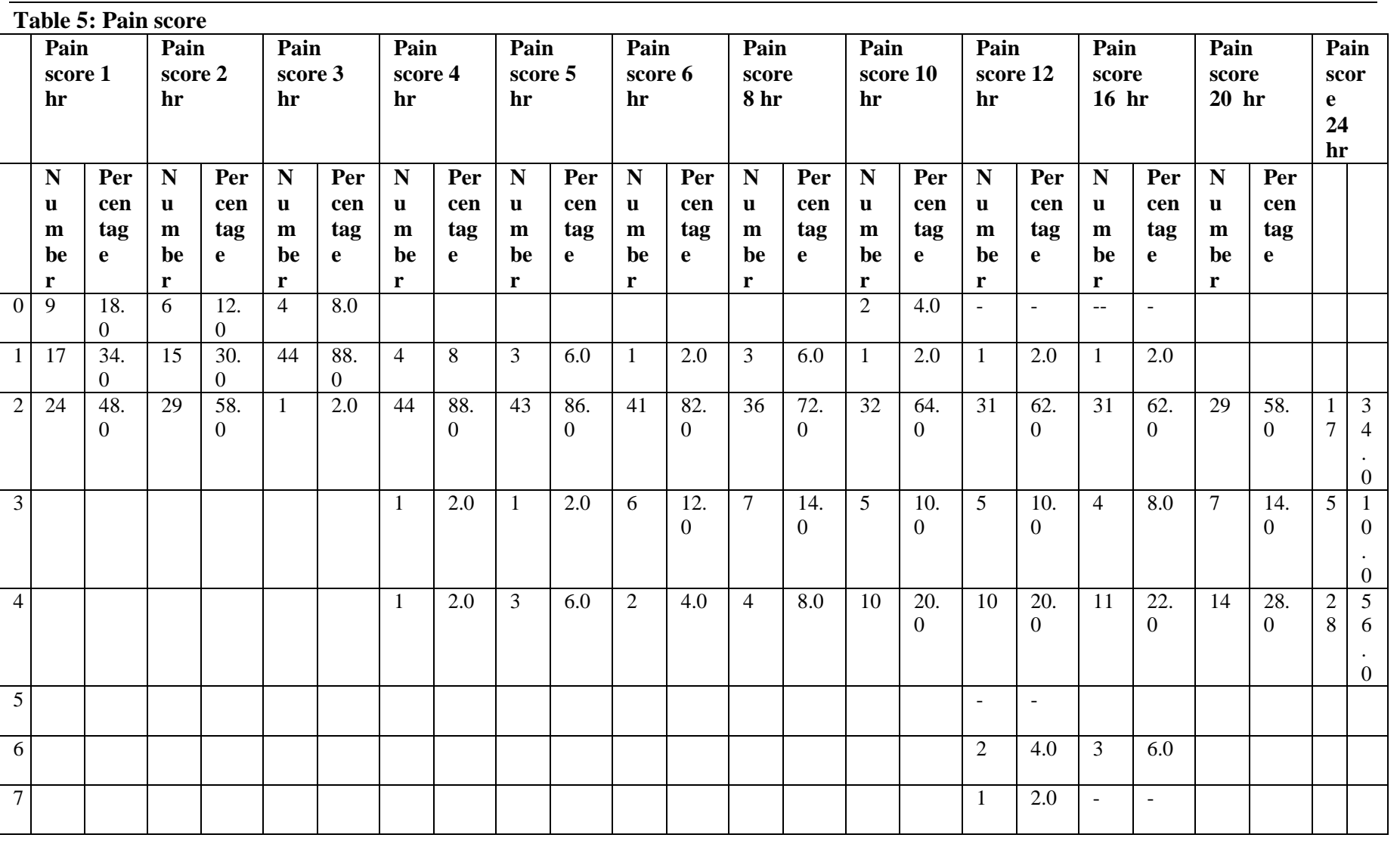

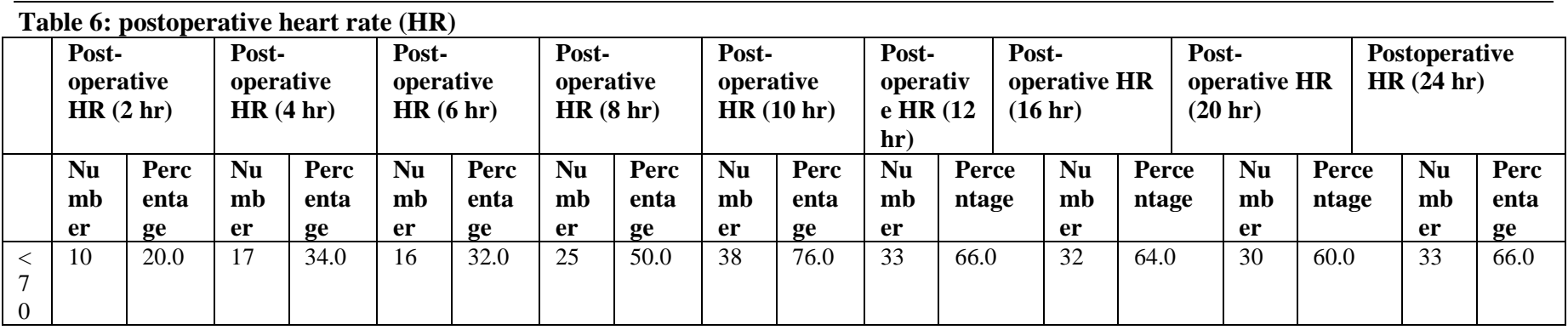




\begin{tabular}{|l|l|l|l|l|l|l|l|l|l|l|l|l|l|l|l|l|l|l|}
\hline $\begin{array}{l}7 \\
0 \\
-\end{array}$ & 23 & 46.0 & 18 & 36.0 & 23 & 46.0 & 16 & 32.0 & 5 & 10.0 & 11 & 22.0 & 11 & 22.0 & 16 & 32.0 & 17 & 34.0 \\
8 & & & & & & & & & & & & & & & & & & \\
0
\end{tabular}
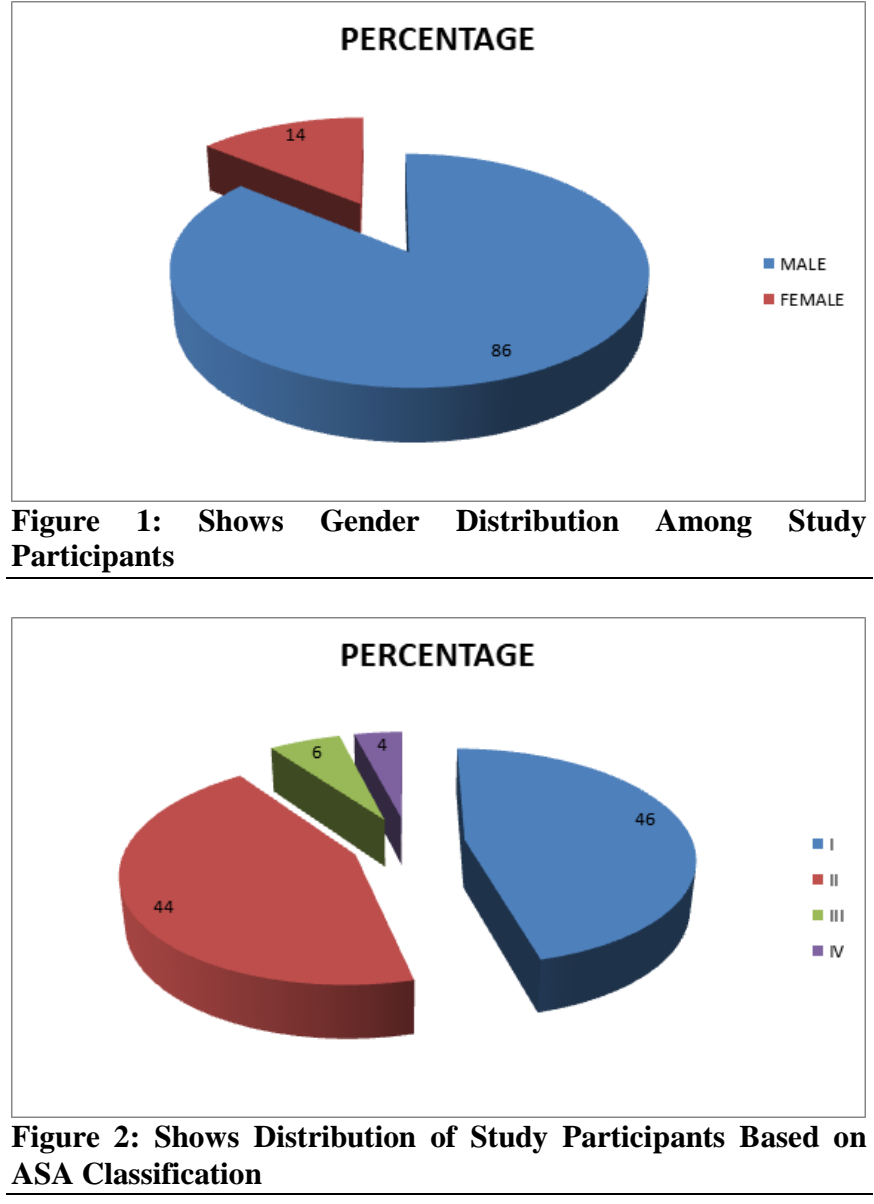

Figure 2: Shows Distribution of Study Participants Based on ASA Classification

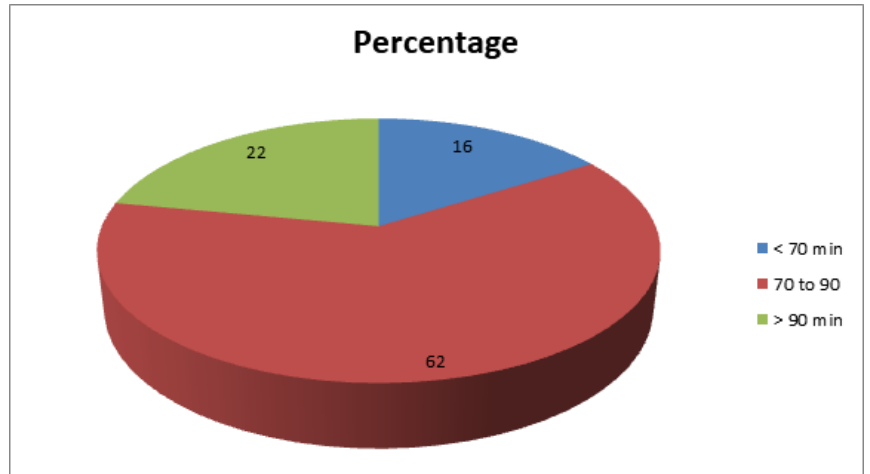

Figure 3: Shows Duration of Surgery Among Study Participants

\section{Conclusion}

In the present study, out of 50 patients, complete analgesia was achieved in maximum (all) patients. Out of 50 patients, the use of rescue analgesics was required only 6 patients. All the patients were satisfied with the experience. Therefore, the result of this study indicates that combined sciatic and femoral nerve block is a safe and effective method for patients undergoing elective and emergency lower limp surgeries.

\section{References}

1. Chang A, White BA. Peripheral Nerve Blocks. In: StatPearls [Internet]. Treasure Island (FL): StatPearls Publishing; 2019 [cited 2019 Jun 23].

2. Hadzic A. Pharmacology. In: Hadzic's Textbook of Regional Anesthesia and Acute Pain Management [Internet]. 2nd ed. New York, NY: McGraw-Hill Education; 2017.

3. Kathuria S, Gupta S, Dhawan I. Dexmedetomidine as an adjuvant to ropivacaine in supraclavicular brachial plexus block. Saudi J Anaesth 2015;9(2):148-154.

4. Marhofer D, Kettner SC, Marhofer P, Pils S, Weber M, Zeitlinger M. Dexmedetomidine as an adjuvant to ropivacaine prolongs peripheral nerve block: a volunteer study. Br J Anaesth. 2013;110(3):438-442.

5. Ammar AS, Mahmoud KM. Ultrasound-guided single injection infraclavicular brachial plexus block using bupivacaine alone or combined with dexmedetomidine for pain control in upper limb surgery: A prospective randomized controlled trial. Saudi J Anaesth. 2012;6(2):109-14.

6. Hunter JC, Fontana DJ, Hedley LR, Jasper JR, Lewis R, Link RE, et al. Assessment of the role of $\alpha 2$-adrenoceptor subtypes in the antinociceptive, sedative and hypothermic action of dexmedetomidine in transgenic mice. Br J Pharmacol. 1997;122(7):1339-44.

7. Kosugi T, Mizuta K, Fujita T, Nakashima M, Kumamoto E. High concentrations of dexmedetomidine inhibit compound action potentials in frog sciatic nerves without alpha(2) adrenoceptor activation. Br J Pharmacol. 2010;160(7):1662-76.

8. Zhang H, Zhou F, Li C, Kong M, Liu H, Zhang P, et al. Molecular mechanisms underlying the analgesic property of intrathecal dexmedetomidine and its neurotoxicity evaluation: an in vivo and in vitro experimental study. PloS One. 2013;8(2):55556.

9. Abdallah FW, Brull R. Facilitatory effects of perineural dexmedetomidine on neuraxial and peripheral nerve block: a systematic review and meta-analysis. Br J Anaesth. 2013;110(6):91525 .

10. Aksoy M, Dostbil A, Ince I, Ahiskalioglu A, Alici HA, Aydin A, et al Continuous spinal anesthesia versus ultrasound-guided combined psoas compartment-sciatic nerve block for hip replacement surgery in high-risk elderly patients: a prospective randomized study. BMC Anesthesiol. 2014;14(1):99.

11. Akkaya A, Tekelioglu UY, Demirhan A, Ozturan KE, Bayir $\mathrm{H}$ Kocoglu H, et al. Ultrasound-guided femoral and sciatic nerve blocks combined with sedoanalgesia versus spinal anesthesia in total knee arthroplasty. Korean J Anesthesiol. 2014;67(2):90-5.

12. Bansal L, Attri JP, Verma P. Lower limb surgeries under combined femoral and sciatic nerve block. Anesth Essays Res. 2016;10(3):4326.

13. Kanazi GE, Aouad MT, Jabbour-Khoury SI, Al Jazzar MD, Alameddine MM, Al-Yaman R, et al. Effect of low-dose dexmedetomidine or clonidine on the characteristics of bupivacaine spinal block. Acta Anaesthesiol Scand. 2006;50(2):222-7.

14. Helal SM, Eskandr AM, Gaballah KM, Gaarour IS. Effects of perineural administration of dexmedetomidine in combination with bupivacaine in a femoral-sciatic nerve block. Saudi J Anaesth. 2016;10(1):18-24.

15. Palkhiwala B, Bhatt P. Study of Combined Femoral and Sciatic Nerve Blocks for Lower Limb Surgical Procedures. Gujarat Med J. 2015;8:23-7.

16. Zaric D, Boysen K, Christiansen C, Christiansen J, Stephensen S, Christensen B. A comparison of epidural analgesia with combined 
continuous femoral-sciatic nerve blocks after total knee replacement. Anesth Analg. 2006;102(4):1240-1246.

17. Singh RKA, Juma THA, Haifi MBA, Nour A. Amputation of Lower
Extremity in Diabetic and High-Risk Patients under Peripheral Nerve Blocks (Combined Sciatic and 3-in-1 Femoral Blocks). Kuwait Med J. 2001;33(4):310-316.

Copyright: (C) the author(s), 2020. It is an open-access article distributed under the terms of the Creative Commons Attribution License (CC BY 4.0), which permits authors to retain ownership of the copyright for their content, and allow anyone to download, reuse, reprint, modify, distribute and/or copy the content as long as the original authors and source are cited.

How to cite this article: Prasad GVK, Jaishree VS. Dexmedetomidine as an Adjuvant in Sciatic Nerve Block for Lower Limb Surgeries: An Observational Study. Acad. Anesthesiol. Int. 2020;5(1):114-119.

DOI: dx.doi.org/10.21276/aan.2020.5.1.23

Source of Support: Nil, Conflict of Interest: None declared. 